\title{
TINGKAT STRES DENGAN PERILAKU MEROKOK PADA REMAJA LAKI - LAKI
}

\author{
Iceu Amira D.A., \& Hendrawati \\ Dosen Dep. Keperawatan Jiwa Fakultas Keperawatan UNPAD \\ Email: iceuamira@yahoo.co.id
}

\begin{abstract}
Abstrak
Penelitian ini dilatarbelakangi dengan kejadian stres yang bisa dialami oleh siapa saja termasuk pada masa remaja, salah satunya adalah mahasiswa, baik di perguruan tinggi, institut atau akademi. Salah satu dampak stres pada remaja adalah perilaku merokok. Berdasarkan studi pendahuluan di Akademi Keperawatan Pemerintah Kabupaten Garut didapatkan data dari 20 orang remaja laki-laki yaitu 17 orang perokok (85\%) dan alasan terbanyak karena stres ada 12 orang (60\%). Tujuan penelitian ini untuk mengetahui hubungan tingkat stres dengan perilaku merokok pada remaja laki-laki di Akademi Keperawatan Pemerintah Kabupaten Garut. Penelitian ini adalah penelitian kuantitatif menggunakan desain deskriptif korelasional. Populasi penelitian dengan total sampling pada 131 remaja laki-laki. Analisa data dengan uji chi-squar dengan hasil hampir seluruh remaja laki-laki mengalami stres ringan, dan sebagian besar remaja laki-laki perokok ringan. Analisis uji chi-square diperoleh nilai $p(p$-value $)=0.040$, artinya terdapat proporsi yang signifikan diantara kedua kelompok tersebut atau terdapat hubungan yang bermakna antara tingkat stres dengan perilaku merokok ( $p$ value < dari 0,05). Nilai Odds Ratio (OR) diperoleh sebesar 3,1 artinya remaja laki- laki yang mengalami stres sedang memiliki risiko untuk merokok sedang sebesar 3,1 kali dibandingkan dengan stres ringan. Terdapat hubungan yang bermakna antara tingkat stress dengan perilaku merokok.
\end{abstract}

Kata Kunci: Tingkat Stres, Perilaku Merokok, Remaja Laki-laki

\begin{abstract}
This study is based on stressful events that can be experienced by anyone including in adolescence, one of whom is a student, either in college, institute or academy. One of the effects of stress on teenagers is smoking behavior. Based on preliminary study at Akademi Keperawatan Pemerintah Kabupaten Garut obtained data from 20 teenage boys that is 17 people smoker (85\%) and the reason there is because there are 12 people $(60 \%)$. The purpose of the study to determine the relationship of health with smoking behavior in adolescent boys in the Akademi Keperawatan Pemerintah Kabupaten Garut. This research is quantitative research using descriptive correlational design. The population in this study with total sampling in 131 male adolescents. Data analysis with chi-square test. Result: almost boys suffering from mild stress, and most teenage boys who suffer from mild smokers, The result of analysis with chi-square test obtained $p$ value ( $p$-value) $=0,040$, there is significant significance between both groups the orthere is an active relationship between stress levels and smoking behavior, because $p$ value <of 0,05 . The results of the next analysis resulted in an Odds Ratio (OR) of 3,1 said teenage boys who are under stress are at moderate risk of moderate smoking 1 times compared with mild stress. There is an active relationship between stress levels and smoking behavior.
\end{abstract}

Keywords: Level of stress, smoking habit 


\section{PENDAHULUAN}

Stres pada remaja penyebabnya adalah hal-hal yang besar dan tak terduga, misalnya karena orang tuanya bercerai, sedang patah hati atau baru mengalami kecelakaan, bisa juga penyebabnya karena masalah-masalah umum dalam kehidupan sehari- hari. Fase awal dunia remaja merupakan masa yang membuat stres. Penyebab stres pada masa remaja kebanyakan adalah masalah yang menyangkut teman sebaya, masalah keluarga, hubungan dengan orang tua, atau masalah yang berkaitan dengan sekolah (Nusya, 2010), selanjutnya menurut Ariandhita (2010) sumber stres pada remaja yaitu ujian dan pekerjaan rumah (masalah di sekolah), bullying atau intimidasi dalam lingkungan pertemanan, obat-obatan dan alkohol, masalah keluarga.

Stres pada remaja bisa terjadi dimana saja termasuk di Akademi keperawatan Pemerintah Kabupaten Garut yang merupakan salah satu perguruan tinggi di wilayah kabupaten Garut, dimana terdapat jumlah keseluruhan mahasiswa sebanyak 435 orang yang terdiri dari pria 226 orang dan wanita 209 orang. Dari studi pendahuluan di Akademi Keperawatan Pemerintah Kabupaten Garut didapatkan data melalui kuesioner dari 20 orang mahasiswa laki-laki yaitu 3 orang bukan perokok dan 17 orang perokok, alasan merokok karena stres ada 12 orang, mereka menyatakan stres karena terlalu banyak tugas di kampus, tidak berminat kuliah di Akper, tidak menyenangi sebagian pelajaran, tidak dapat konsentrasi bila di kelas.

Hasil wawancara bila mereka stres timbul gejala merasa tegang, merasa takut, sukar konsentrasi, jantung berdebar debar, pernafasan lebih cepat, berkeringat, sulit tidur, suka mengeluh sedangkan alasan merokok yang lain karena sudah terbiasa 3 orang dan bila setelah makan 2 orang, kemudian penulis membandingkan dengan Akper Bidara Mukti dari 20 orang mahasiswa didapatkan 5 orang yang tidak merokok dan 15 orang perokok, alasan merokok karena stres ada 8 orang, jika setelah makan 3 orang dan bila mau saja ada 4 orang, data lain yang mendukung yaitu adanya mahasiwa yang sering bolos kuliah sebanyak $4,42 \%$, yang drop out sebanyak $6,2 \%$ dan nilai yang kurang sebanyak $62,83 \%$. Tujuan penelitian ini adalah untuk mengetahui hubungan tingkat stress dengan perilaku merokok pada remaja laki-laki di Akademi Keperawatan Pemerintah Kabupaten Garut.

\section{METODE PENELITIAN}

Jenis penelitian ini menggunakan deskriptif korelasi yaitu mendeskriptifkan suatu keadaan dan menjelaskan tentang hubungan antara variable yang diteliti, dari obyek yang akan diteliti. Rancangan penelitian menggunakan cross sectional yaitu penelitian melakukan pengukuran sesaat terhadap variabel penelitian (Alimul, 2009).

Selanjutnya dibuat analisis secara kuantitatif setelah dikumpulkan, peneliti mencoba mencari hubungan antara dua variabel yaitu variabel bebas (independen) dan varibel terikat (dependen), yang termasuk variabel bebas dalam penelitian ini yaitu tingkat stres dan variabel terikatnya adalah perilaku merokok, melalui uji hipotesa yang telah dirumuskan.

Populasi dalam penelitian ini yaitu seluruh remaja laki-laki yang merokok berjumlah 131 orang yang terdiri dari: tingkat $1=51$ orang, tingkat $2=42$ orang dan tingkat $3=38$ orang yang ada di Akademi Keperawatan pemerintah Kabupaten Garut. Sedangkan sampel yang diambil sebanyak 131 orang atau total sampling.

Instrumen yang digunakan untuk mengukur tingkat stress pada mahasiswa yaitu berupa kuesioner dari DASS (Depression anxiety stress scale) 42. Kuesioner dari DASS ini hanya diambil stres saja sesuai dengan tujuan penelitian. Skala yang digunakan yaitu skala ordinal. Dimana rentang dalam penelitian ini terbagi menjadi: stres ringan, stres sedang dan stres berat. Data analysis menggunakan DASS 42. 


\section{HASIL DAN PEMBAHASAN}

Tabel 1. Tingkat Stres Pada Remaja laki-laki

\begin{tabular}{ccc}
\hline Tingkat Stres & Frekuensi & Presentasi \\
\hline Ringan & 115 & \\
\hline Sedang & 16 \\
\hline Berat & 0 \\
\hline Jumlah & 131 \\
\hline
\end{tabular}

Tabel 2. Hubungan Tingkat Stres dengan Perilaku Merokok

\begin{tabular}{cccc}
\hline \multirow{2}{*}{$\begin{array}{c}\text { Tingkat } \\
\text { Stres }\end{array}$} & \multicolumn{2}{c}{ Perilaku Merokok } & Jumlah \\
\cline { 2 - 3 } & Ringan & Sedang & \\
\hline Ringan & $\begin{array}{c}87 \\
(75,7 \%)\end{array}$ & $\begin{array}{c}28 \\
(24,3)\end{array}$ & 115 \\
\hline Sedang & $\begin{array}{c}8 \\
(50 \%)\end{array}$ & $\begin{array}{c}8 \\
(50 \%)\end{array}$ & 16 \\
\hline Jumlah & 95 & 36 & 131 \\
\hline$\rho=0,04$ dan OR $=3,1$ & &
\end{tabular}

Proporsi remaja laki-laki dengan tingkat stres ringan hampir seluruhnya memiliki perilaku merokok ringan dibandingkan remaja laki-laki dengan tingkat stres sedang dan merokok ringan. Hasil analisis dengan uji chi-square diperoleh nilai $p(p$-value $)=0.040$, sesuai nilai hasil fisher's Exact Test, karena ada salah satu sel dengan nilai $E<$ dari 5 artinya terdapat proporsi yang signifikan diantara kedua kelompok tersebut atau terdapat hubungan yang bermakna antara tingkat stres dengan perilaku merokok, karena $p$ value $<$ dari 0,05 .

Hasil analisis selanjutnya diperoleh nilai Odds Ratio (OR) sebesar 3,1 artinya remaja laki-laki yang mengalami stres sedang memiliki risiko untuk merokok sedang sebesar 3,1 kali dibandingkan dengan stres ringan. Pada pembahasan menjelaskan sesuai dengan hasil penelitian yang telah diuraikan sebelumnya yaitu tingkat stres karena tugas akademik, perilaku merokok serta hubungan antara tingkat stres dengan perilaku merokok. Hasil penelitian yaitu hampir seluruhnya remaja laki-laki $(75,7 \%)$ mengalami stres ringan, tidak ada yang mengalami stres berat, hal ini karena remaja laki-laki berasumsi bahwa tugas akademik itu merupakan suatu kewajiban yang harus dilaksanakan sehingga walaupun banyak tugas akademik tetapi mereka tetap melaksanakannya dan apabila sudah menyelesaikan sesuai waktu yang ditentukan mereka lebih tenang.

Perilaku merokok adalah aktivitas seseorang yang merupakan respons orang tersebut terhadap rangsangan dari luar, sedangkan merokok adalah membakar tembakau kemudian dihisap (Istiqomah, 2003). Hasil penelitian ini menunjukan bahwa jumlah remaja laki-laki yang termasuk perilaku merokok ringan sebagian besar yaitu $72,5 \%$ dibandingkan dengan yang sedang yaitu $27,5 \%$, sedangkan yang berat dan sangat berat tidak terdapat dalam hasil penelitian ini. Remaja laki-laki sebagian besar yaitu perokok ringan yaitu mereka merokok dalam sehari antara 1 sampai kurang dari 10 batang, alasan mereka merokok hanya untuk menenangkan saja dan cara untuk mengurangi stres, juga mereka merokok karena iseng, bila setelah makan dan ikut-ikutan saja, karena didalam rokok terdapat zat berupa nikotin bereaksi di bagian otak yang mengatur bagian perasaan nyaman dan dihargai. Hal tersebut baru diketahui oleh para ahli setelah dilakukan penelitian lebih lanjut, mereka menemukan bahwa perjalanan nikotin di bagian otak ternyata dapat mencapai tingkatan dopamin yang merupakan transmisi saraf yang mempunyai fungsi menciptakan perasaan nyaman dan dihargai anusia. Perilaku merokok karena stres termasuk perilaku yang diperoleh karena perasaan negatif, dimana merokok digunakan untuk mengurangi perasaan tersebut, misalnya bila sedang marah, cemas dan gelisah (Asmara, 2008).

Lama merokok sebagian besar $(74,04 \%)$ lebih dari 1 tahun, mulai merokok hampir seluruhnya $(88,55 \%)$ lebih dari 10 tahun, hampir seluruhnya $(87,79 \%)$ orang tua tidak pernah memberikan jatah untuk membeli rokok, hampir seluruhnya $(92,37 \%)$ 
menghisap rokok filter, sebagian besar $(64,12 \%)$ tidak ada niat untuk berhenti merokok, sebagian besar $(70,23 \%)$ merokok tidak mengganggu kesehatan, sebagian besar $(63,36 \%)$ tidak ada yang menegur kalo merokok. Menurut hasil penelitian komalasari yaitu kepuasan psikologis atau stres dapat mempengaruhi terhadap perilaku merokok remaja.

Kepuasan psikologis yaitu dimana setelah mereka merokok akan merasakan tenang. Kepuasan psikologis mempunyai hubungan yang erat dengan perilaku merokok pada remaja sebesar $40,9 \%$. Hal ini memberikan gambaran bahwa perilaku merokok pada remaja dianggap memberikan kenikmatan dan menyenangkan, kondisi yang paling banyak perilaku merokok adalah ketika remaja dalam tekanan (stres) yaitu sebanyak 40,86\% yaitu tekanan stress akademik.

Patofisiologi stres dengan perilaku merokok yaitu karena pada rokok terdapat zat berupa nikotin yang bereaksi di bagian otak dan dapat mencapai tingkatan dopamin yang merupakan transmisi saraf yang mempunyai fungsi menciptakan perasaan nyaman dan dihargai manusia, oleh karena itu dalam keadaan stres akan melakukan perilaku merokok sebagai cara mengatasi masalah atau stres.

Hasil analisis bivariat dengan uji chisquare menunjukan bahwa ada hubungan yang signifikan antara tingkat stres dengan perilaku merokok pada remaja laki-laki, hal tersebut menunjukan bahwa hipotesis diterima atau Ho ditolak dan Ha diterima, yaitu remaja laki-laki dengan tingkat stres sedang beresiko sebesar 3,1 kali untuk menjadi perokok sedang dibandingkan dengan tingkat stres ringan. Stres memiliki pengaruh terhadap perilaku merokok pada remaja laki-laki. Semakin tinggi tingkat stres memiliki pengaruh yang sangat signifikan terhadap perilaku merokok. Stres adalah reaksi atau respons tubuh terhadap stressor psikososial (tekanan mental atau beban kehidupan), menurut Dadang Hawari (Sunaryo, 2004), stres adalah ketegangan, dan tekanan (Wangsa, Teguh 2010), selanjutnya menurut Tri Akoso (2009) menyatakan stres adalah cara tubuh kita bereaksi terhadap ketegangan, kegelisahan, dan tugas-tugas berat yang harus dihadapi sehari- hari.

Remaja laki-laki merupakan populasi yang sangat rentan terhadap stres karena remaja laki-laki dihadapkan pada berbagai masalah dan tuntutan yang spesifik, diantaranya penyesuaian diri dengan lingkungan yang baru, faktor akademik, tugas-tugas yang banyak dan penyesuaian dengan peran yang baru dan harapan sosial secara mandiri, hal ini sesuai menurut Ariandhita (2010), sumber stres pada remaja yaitu ujian dan pekerjaan rumah (masalah di sekolah), bullying atau intimidasi dalam lingkungan pertemanan, obat-obatan dan alkohol serta masalah keluarga. Hal ini didukung juga oleh Booker (2004) bahwa perilaku merokok pada remaja berhubungan dengan perilaku penuh stres dalam kehidupan sehari-hari.

Laki-laki mempunyai respon stres tertentu yang disebabkan oleh faktor-faktor emosioanl yang berbeda dengan wanita. Hal ini di dukung oleh Nasution (2008) respon stress pada remaja laki-laki cenderung lebih berperilaku agresif. Remaja laki-laki yang mengalami stres akan melakukan perbuatan negatif seperti mengkonsumsi rokok dan alkohol.

Jadi semakin tinggi tingkat stres pada remaja laki-laki di Akademi Keperawatan Pemerintah Kabupaten Garut maka akan semakin tinggi pula perilaku merokok. Hasil analisis selanjutnya diperoleh nilai Odds Ratio (OR) sebesar 3,1 artinya mahasiswa yang stres sedang memiliki risiko untuk merokok sedang sebesar 3,1 kali dibandingkan dengan stres ringan.

\section{KESIMPULAN}

Dari hasil penelitian ini ditemukan ada hubungan yang signifikan antara tingkat stres dengan perilaku merokok, dimana nilai $\mathrm{p}=0,040$. Perlu dilakukan pembinaan tentang stres dan perilaku merokok yaitu dalam mengatasi masalah stres dilakukan manajemen stres dengan kegiatan-kegiatan 
yang dapat menghilangkan stres seperti rekreasi, olah raga, kesenian dan mengadakan kegiatan bakti sosial supaya mereka dapat menyalurkan stres kepada kegiatan yang bermanfaat. Untuk mengatasi perilaku merokok dengan diadakan pendidikan kesehatan kepada remaja lakilaki agar mereka mengetahui bahaya dari merokok.

\section{DAFTAR PUSTAKA}

Akper Pemkab Garut, (2012). Buku Panduan Akper Pemkab Garut.

Alimul. A., (2009). Metode Penelitian Klinis. Bina Rupa Aksara: Jakarta.

Asmara, A., dkk, (2008). Rokok Dan Kesehatan. Penerbit CV Wahana Iptek: Bandung

Azwar S., (2004). Reliabilitas Dan Validitas, Penerbit: Pustaka Pelajar: Jogjakarta.

Firdaus, (2010). Dilemanya Sebuah Rokok, Penerbit: CV Aksara, Bekasi

Fuadah, M., (2011). Gambaran Faktor-

Hutapea, (2013). Why Rokok Tembakau dan Peradaban Manusia, Bee Media Indonesia: Jakarta.

Notoatmodjo, (2005). Promosi Kesehatan Teori dan Aplikasi, PT Rineka Cipta: Jakarta

Ningrat, K., (2005), Metode penelitian Kemasyarakatan, Gramedia Pustaka Utama: Jakarta.

Potter \& Perry, (2005), Buku Ajar Fundamental Keperawatan, Konsep, Proses dan Praktik, Edisi 4 vol 1, EGC, Jakarta.
Rohman, A., (2012). Hubungan antara Tingkat Stres dan Status Sosial Ekonomi Orang Tua Dengan Perilaku Merokok Pada Remaja, diambil dari http://psikologi.or.id tanggal 19 November 2013.

Rasmun, (2004). Stres Koping Dan Adaptasi (edisi pertama). Jakarta: Sagung Seto

Sunaryo, (2004), Psikologi Untuk keperawatan, Penerbit: EGC, Jakarta

Tri A., (2009), Bebas Stres, Penerbit: Kanisius: Yogjakarta

Wangsa, T., (2010). Stress Dan Depresi, Oryza: Jogjakarta

Widhiyanto, A., (2011). Hubungan Stress dengan Peningkatan Aktifitas Merokok pada Pria Dewasa Di Rt $01 \mathrm{Rw} 06$ Desa Sinopekso Krasa Probolinggo. www.Stikeshafshawaty.com, Diambil Tanggal 3 Oktober 2013.

Wijoyo, (2011), Mencegah Dan Mengatasi Stres, Penerbit: Bee Media Pustaka. Jawa Barat.

WHO, (2008). Report on Tobacco Epidemic. Nusantara news. 10 negara jumlah perokok terbesar di dunia. Wordpress.com (2009) 05/ 31, Diambil tanggal 23 Noveber 2013.

Wong, D.L., Eaton, M.H., Wilson,D., et al.(2009). Wong's essentials of pediatric nursing, 6th ed. St.Louis: Mosby Year Book.

Yusuf, S., (2006). Psikologi Perkembangan Anak Dan Remaja, Penerbit: PT Remaja Rosda Karya, Bandung. 